\title{
Effect of Simulated Wind-Driven Rain on Duration and Distance of Dispersal of Xanthomonas axonopodis pv. citri from Canker-Infected Citrus Trees
}

\author{
C. H. Bock, USDA-ARS-USHRL, 2001 S. Rock Rd., Ft. Pierce, FL 34945; P. E. Parker, Center for Plant Health \\ Science and Technology Pest Detection Diagnostics and Management Laboratory, USDA-APHIS, Moore Air Base, \\ Edinburg, TX 78541; and T. R. Gottwald, USDA-ARS-USHRL, 2001 S. Rock Rd., Ft. Pierce, FL 34945
}

\begin{abstract}
Bock, C. H., Parker, P. E., and Gottwald, T. R. 2005. Effect of simulated wind-driven rain on duration and distance of dispersal of Xanthomonas axonopodis pv. citri from canker-infected citrus trees. Plant Dis. 89:71-80.

Dynamics of dispersal of the bacteria that causes citrus canker (Xanthomonas axonopodis pv. citri) were assessed in simulated wind-driven rain splash. The wind/rain-splash events were simulated using electric blowers to generate turbulent wind $\left(15\right.$ to $\left.20 \mathrm{~m} \mathrm{~s}^{-1}\right)$ and sprayer nozzles to produce water droplets entrained in the wind flow. The splash was blown at an inoculum source of canker-infected trees $1 \mathrm{~m}$ downwind. The splash downwind of the source of the infected trees was collected by vertical panel samplers and funnel samplers. The duration over which bacteria were dispersed in spray was assessed in continuous wind at intervals from 0 to 52 $\mathrm{h}$ after commencing the simulated rain splash event. In one experiment on 11 February 2003, a total of $1.48 \times 10^{6}$ bacteria were collected by panels $1 \mathrm{~m}$ downwind from the inoculum source during the first $10 \mathrm{~min}$ of dispersal, but the numbers declined to $3.60 \times 10^{5}$ bacteria after $1 \mathrm{~h}$ and ranged between $1.42 \times 10^{5}$ and $1.93 \times 10^{4}$ up to $52 \mathrm{~h}$. In a more detailed study (15 July 2003) of dispersal duration over $4 \mathrm{~h}$, the greatest quantity of bacteria collected by panel samplers were dispersed in the first 5-min period $\left(1.01 \times 10^{8}\right.$ bacteria collected $)$. By $10 \mathrm{~min}$ after initiation of dispersal, approximately one-third $\left(3.09 \times 10^{7}\right.$ bacteria collected $)$ of the initial number was being dispersed, and by the end of the first hour, only one-tenth $\left(1.31 \times 10^{7}\right.$ bacteria collected $)$ of the initial quantity was dispersed. Funnel samplers placed at ground level under the trees showed a similar trend. The distance to which bacteria were dispersed in wind-blown splash was also tested under simulated conditions: on 18 September 2003, bacteria were collected by panel samplers at all distances sampled $(1,2,4,6,8,10$, and $12 \mathrm{~m})$ with the greatest number of bacteria deposited at $1 \mathrm{~m}\left(4.93 \times 10^{6}\right.$ bacteria collected), while $2.22 \times 10^{3}$ bacteria were deposited over a 10 -min period $12 \mathrm{~m}$ from the inoculum source. Wind speed declined from $19.5 \mathrm{~m} \mathrm{~s}^{-1}$ upwind of the trees to $2.8 \mathrm{~m} \mathrm{~s}^{-1} 1 \mathrm{~m}$ downwind, and by $4 \mathrm{~m}$ downwind from the inoculum source, movement was similar to the surrounding air. The data on duration and distance of dispersal were best described by power law regression models compared to exponential models. Citrus canker is readily dispersed in wind-driven rain and is dispersed in large quantities immediately after the stimulus occurs, upon which wind-driven splash can disperse inoculum over a prolonged period and over a substantial distance.
\end{abstract}

Additional keywords: epidemiology, splash dispersal, wind dispersal

Xanthomonas axonopodis pv. citri is a plant-pathogenic bacterium that infects several species of citrus, causing citrus canker. Symptoms are manifest as erumpent, necrotic lesions on leaves, shoots, branches, and fruit, which can result in severe yield loss due to fruit and leaf drop. On fruit, the unsightly blemishes lead to reduced marketability $(10,28)$. The pathogen occurs in many humid-wet tropical and subtropical citrus growing regions and

Corresponding author: C. H. Bock

E-mail: cbock@ushrl.ars.usda.gov

Accepted for publication 30 August 2004.

\section{DOI: 10.1094/PD-89-0071}

This article is in the public domain and not copyrightable. It may be freely reprinted with customary crediting of the source. The American Phytopathological Society, 2005 was most recently discovered in the Miami area of Florida in 1995 (22,28). Due to the threat posed to the Florida citrus industry by the disease, an eradication program was instigated $(15,17,28)$. Indeed, canker eradication has been and is being undertaken in many areas of the world alongside chemical (copper sprays) and cultural disease management practices such as windbreaks (18) to minimize disease (28).

Wind and rain are established agents of dispersal for many plant-pathogenic fungi $(1,7,20,23)$, but there are few examples that demonstrate the combination of wind and rain as dispersal agents for bacterial pathogens of plants $(2,8,24,33,34)$. Observations on angular leaf spot of cotton (5) suggest that the combined action of wind and rain would be important for dispersal of pathogens of citrus in the southeastern United States, where frequent, strong storms occur during summer (6). Subse- quently, the role of splash in dispersing $X$. axonopodis pv. citri was demonstrated $(27,29)$, and a role of wind was indicated (29). Furthermore, studies of the spatial and temporal distribution of citrus canker also suggest the combined effect of wind and splash in dispersing $X$. axonopodis pv. citri $(3,12,13,16,19)$, and these are the basis of the $1,900-\mathrm{ft}(570-\mathrm{m})$ diameter eradication zone legislated in Florida (17), where disease gradients up to $1,000 \mathrm{ft}$ (300 $\mathrm{m})$ were described. But although gradients of disease have been characterized for citrus canker and other bacterial diseases $(7,24)$, and provide a measure of the overall success of inoculum at causing disease at distances from the source, disease gradients do not address the fundamental but complex processes of inoculum production, dispersal, and infection (24). Inoculum deposition gradients describe the potential of the pathogen to be dispersed and have not been demonstrated for $X$. axonopodis pv. citri, although bacteria have been found $32 \mathrm{~m}$ from infected plants (31), showing their dispersability. Besides understanding the process of dispersal, characterizing inoculum gradients of $X$. axonopodis pv. citri and the effect of wind on splash dispersal of the bacteria can provide useful insight into the value of some cultural disease management strategies, including windbreaks (18) that might reduce dispersal of wind-blown splash.

Factors identified that influence the quantity of $X$. axonopodis pv. citri dispersed in rain splash include lesion age $(27,32)$ and ambient temperature $(21,31)$. In subtropical regions, cooler temperatures during winter reduce the number of bacteria. Temperatures between 20 and $30^{\circ} \mathrm{C}$ support good growth of $X$. axonopodis pv. citri (26), so in tropical environments, the quantity of bacteria produced are high throughout the year (27). Studies have shown that a large resident population of canker bacteria exists in lesions prior to a dispersal stimulus $(27,31)$. Serizawa et al. (30) initially found that bacteria were dispersed in small quantities, but later data (29) suggested the number of bacteria collected during rain alone was only low during the early phase of dispersal $\left(10^{2}\right.$ to $10^{3}$ bacteria per $\mathrm{ml}$ ), but increased to $10^{3}$ to $10^{4}$ bacteria per $\mathrm{ml}$ after the first hour. In contrast, other studies found infected plants exposed to rain alone initially dispersed large quantities $\left(10^{6}\right.$ to $10^{7}$ bacteria 
per ml), which declined to $10^{3}$ to $10^{4} \mathrm{bac}$ teria per $\mathrm{ml}$ after approximately $1 \mathrm{~h}$ (27). Timmer et al. (32) also found the quantity of bacteria exuded from single, detached lesions declined rapidly during the first hour of dispersal from $10^{4}$ to $10^{5}$ bacteria per ml to $10^{2}$ to $10^{3}$ bacteria per ml. However, under successive natural rain events (every 1 to $2 \mathrm{~h}$ ), the quantity of bacteria in rainwater collected under plants remained relatively constant $\left(10^{5}\right.$ bacteria per $\left.\mathrm{ml}\right)$, suggesting populations were maintained and/or regenerated rapidly between storms (31). The ability of the bacteria to be produced rapidly and to be dispersed in large numbers will depend on bacterial reproduction, how many bacterial cells enter the rain splash, and how readily the splash becomes entrained in wind.

The objectives of these experiments were to (i) investigate the quantities of bacteria being dispersed from infected trees under a simulated wind/rain event, (ii) investigate the temporal dynamics of dispersal of $X$. axonopodis pv. citri from infected plants in simulated wind-driven rain splash, and (iii) assess the dispersal gradient and the distance to which $X$. axonopodis pv. citri were dispersed during a simulated wind/rain event.

\section{MATERIALS AND METHODS}

Source of inoculum. The source of inoculum was a group of three or five infected grapefruit trees (Citrus $\times$ paradisi Macf. cv. Ruby Red) in 38-liter containers (ca. $1.5 \mathrm{~m}$ tall with a crown ca. $0.8 \times 0.8$ $\mathrm{m})$. These trees were infected with the
Asiatic strain (A-strain) of citrus canker, and lesions were 2 to 6 months old at the time of the experiments (infection was a combination of inoculation and natural spread). Different groups of trees were used in different experiments, with mean disease incidence (89 to $97 \%$ leaves infected) and severity (6.5 to 13.6 lesions per infected leaf) for each group of plants estimated by assessing infection on a sample of 40 leaves on each of the plants (P. E. Parker, C. H. Bock, and T. R. Gottwald, unpublished).

Wind and rain splash. The wind source was a series of three yard blowers (Leaf Hog model, Black \& Decker, Towson, MD). The blowers were mounted at a height of $107 \mathrm{~cm}$. Three garden hose sprayer nozzles (Orbit/Sunmate 7 Pattern Zinc Pistol Nozzles, Orbit Irrigation Products, Inc., Bountiful, UT) were situated 10 $\mathrm{cm}$ below each blower outlet, and the nozzles were oriented into the air stream (water sprayed from the nozzle entered the wind stream and was blown downwind, Fig. 1). The sprayers were set to the "jet" selection and were connected to a local well water source via a garden hose.

Sampler types and experiment design. Panels and funnels were used to collect the wind-blown splash (Fig. 1). The panels were placed vertically in the line of the wind-blown splash with the center height at $1.3 \mathrm{~m}$. Panels $\left(1,176 \mathrm{~cm}^{2}\right)$ were 131 -fold larger in surface area than the funnels ( 9 $\mathrm{cm}^{2}$ ). The funnels were placed with the outlet through a hole drilled in the lid of a conical collection flask, which was set directly on the ground at set distances from the source of inoculum, depending on the experiment. The panel sample was also directed into a collection vessel at the panel base for further processing. The volume of the sample collected was measured, and the samples were plated using dilution plate technique to count the number of CFU per plate, from which the CFU per $\mathrm{ml}$, per $\mathrm{m}^{2}$, and total quantity of bacteria collected were calculated. The samples were plated on KCB semi-selective media composed of nutrient agar (NA) amended with kasugamycin (16 mg/liter), cephalexin (35 mg/liter), and chlorothalonil (12 $\mathrm{mg} /$ liter tetrachloroisophthalonitrile). In addition to the samples of splash, well water from the subterranean source was also plated out to act as a control. The plates were incubated at $27^{\circ} \mathrm{C}$ for 5 to 7 days prior to counting the colonies of $X$. axonopodis pv. citri.

How long do lesions produce inoculum under a simulated wind-splash event? Two sets of experiments were performed to investigate temporal effects on the quantity of bacteria dispersed in the field. In the first, the wind and splash were maintained over a period of $52 \mathrm{~h}$. The source of inoculum was a group of five plants placed $1 \mathrm{~m}$ downwind of the blower/sprayer system with a row of three plants immediately behind two plants, which were placed across the axis of the wind generated by the blower. Three replicate panels were placed $1 \mathrm{~m}$ downwind from the source of inoculum and perpendicular to the wind. In addition, three replicate funnel samples were attached at the

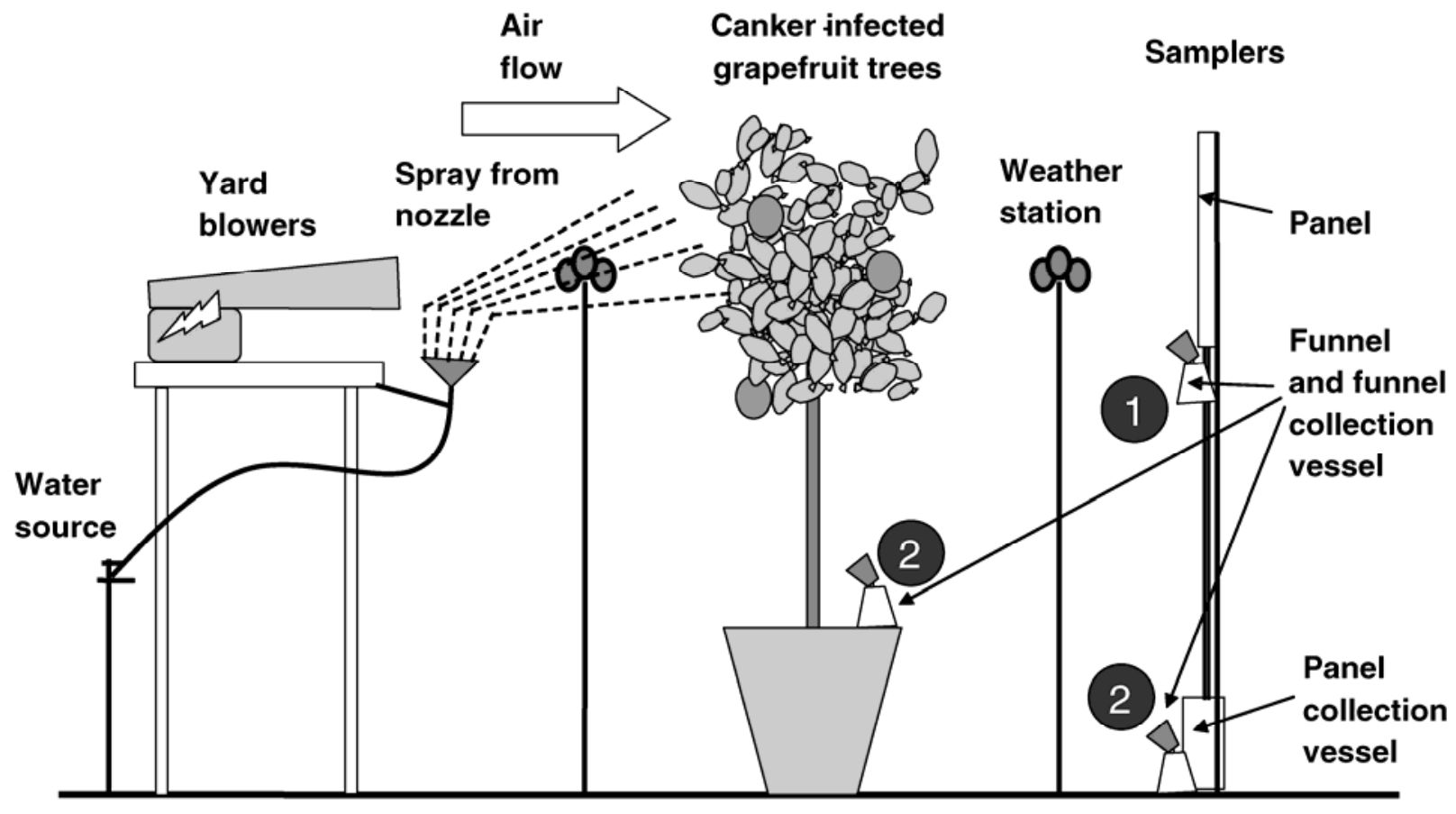

Fig. 1. Relative position of blowers, sprayers, and canker-infected grapefruit trees used to generate wind-blown splash containing Xanthomonas axonopodis pv. citri. Samplers were positioned $1 \mathrm{~m}$ downwind for the duration-of-dispersal experiments, and 1, 2, 4, 6, 8, 10, and 12 $\mathrm{m}$ downwind from the trees during the distance-of-dispersal experiments. Funnels were placed at position 1 for the 52-h duration-of-dispersal experiments ( 1 m from inoculum source) and at position 2 for the 4-h duration-of-dispersal and distance-of-dispersal experiments $(0,4$, and $6 \mathrm{~m}$ from the inoculum source). 
base of each panel. Samples comprised 10min periods of spray collection. Blowers and spray were kept operating continuously, and samples were taken at $0,0.5,1$, $3,5,9,14,19,24,27,30$, and $52 \mathrm{~h}$. The experiment was repeated three times (6 February, 11 February, and 22 April 2003).

To investigate in greater detail the dynamics of dispersal during the first $4 \mathrm{~h}$, a second series of experiments was done. Three plants with 3-month-old infections were used and set up as described above. Collecting periods lasted only $5 \mathrm{~min}$, and samples were taken at $0,10,20,30,45,55$, $65,80,100,120,140,160,180,200,220$, and $240 \mathrm{~min}$ after commencing dispersal. Funnel samplers were placed under the infected plants to collect samples, which were taken at $0,20,45,65,120,180$, and $240 \mathrm{~min}$. Samples were processed as described above. The experiment was repeated three times (15 July, 29 July, and 16 September 2003).

How far can inoculum travel during a simulated wind-splash event? Three plants were placed as described above, and panels were positioned at $1,2,4,6,8,10$, and $12 \mathrm{~m}$ downwind from the plants, and in a staggered manner so as to minimize the risk of a "shadow" effect. Panel size was as previously described, except for the final panel, which was $0.471 \mathrm{~m}^{2}$. Panels at $\geq 6 \mathrm{~m}$ did not sample sufficient spray to collect in the sample container, so it was necessary to wash these panels with water. Fifty milliliters was used for the panels with a surface area of $0.118 \mathrm{~m}^{2}$, and 200 $\mathrm{ml}$ was used for the panel with a surface area of $0.471 \mathrm{~m}^{2}$, from which total bacteria of $X$. axonopodis pv. citri collected were calculated (insufficient spray collected at distances $\geq 6 \mathrm{~m}$ precluded meaningful calculation of bacterial concentration, so the number of bacteria per square meter of panel surface area was calculated after washing the sampler collection surface). Funnels collecting splash into beakers were placed directly below the infected plants and at 2 and $4 \mathrm{~m}$ downwind. Collecting periods lasted $10 \mathrm{~min}$, and the samples were processed as described above. The experiment was replicated three times consecutively on the same day using the same plants and was repeated four times (4 February, 18 April, 26 June, and 18 September 2003).

Measurement of wind speed and direction. Wind speed and direction were monitored using a cup anemometer and a wind vane, respectively, and temperature was recorded using a temperature sensor (Weather Wizard III, Davis Instruments, Hayward, CA). Wind monitors were positioned at a height of $1.10 \mathrm{~m}$. For the duration experiments, one wind monitor was placed upwind $(0.5 \mathrm{~m})$ of the tree canopies, a second downwind $(0.5 \mathrm{~m})$ of the canopy, and a third $15 \mathrm{~m}$ distant to record ambient weather conditions. For the distance experiment, one wind monitor was placed upwind $(0.5 \mathrm{~m})$ of the tree cano- pies, a second downwind $(0.5 \mathrm{~m})$ of the canopy, a third at $4 \mathrm{~m}$ downwind, and the fourth at $10 \mathrm{~m}$ downwind. For all experiments, temperature probes were placed in the windward and leeward sides of the canopy, and in the canopy of a citrus tree ca. $15 \mathrm{~m}$ from the experiment. A fifth independent weather station also recorded weather conditions at the site. Standard deviations were calculated for weather data variables during each sample period.

Data analysis. The data were analyzed using Microsoft Excel 2000 and SAS V9.1.2 (SAS Systems, Cary, NC). Regression analysis (PROC NLIN) was used to investigate temporal and distance effects on the quantity of bacteria collected. Both exponential models $\left(y=a e^{b / x}\right)$ and Gregory's power law model $\left(y=a x^{b}\right)(20)$ were fit to the data from each of the 10 experiments and assessed for goodness of fit using the coefficients of determination $\left(R^{2}\right.$ value), assessment of the standard errors, and residual plots of the estimated parameters for the model. Residuals of the linearized models were estimated and assessed due to heterogeneity of variance (linearized power law model $\log y=a-b$ $\log x$, and exponential model $\log y=a+$ $(b / x)$ ). The linearized version of the power law model was also used to test for heterorepeated on different days. A dummy variable regression analysis was performed for the data sets classed by day to investigate whether they had equal slopes and/or intercepts. Dummy variable regression allows the information on group membership (in this case day of experiment) to be represented in quantitative terms without imposing unrealistic measurement assumptions on the categorical variable (PROC REG was used to investigate the suitability of both the full and reduced models in the dummy variable regression). An analysis of variance (using PROC GLM) was performed on each experiment to investigate the effect of dispersal duration, distance of dispersal, and sampler type on the volume collected, CFU of $X$. axonopodis pv. citri per $\mathrm{ml}$, bacteria per $\mathrm{m}^{2}$ (for the distance experiment), and total $X$. axonopodis $\mathrm{pv}$. geneity of regression between experiments

citri collected (data were log transformed prior to analysis to reduce the heterogeneity of variance due to distance and duration). A Pearson's correlation analysis was performed to investigate association between total number of $X$. axonopodis pv. citri collected, splash volume, and CFU $X$. axonopodis pv. citri per $\mathrm{ml}$ for and between each of the sampler types, and between the volumes collected, CFU $X$. axonopodis pv. citri per $\mathrm{ml}$, total number of $X$. axonopodis pv. citri collected, and prevailing wind direction and temperature. Wind direction was quantified by allotting the highest score (9) to the wind direction aligned with the blower axis and one point less for each 22.5 degrees deviation from the blower axis, so that 1 represented wind blowing directly toward the blowers (zero wind was allotted 8 , as it did not shift the plume or extend its range). This number was then multiplied by the number of minutes the wind blew from that direction during the collecting period, and the resulting numbers were summed to produce a weighted total for each sample period, which was used in the correlation analysis. Linear regression analysis was also used to investigate the relationship between the total quantity of $X$. axonopodis pv. citri collected and CFU $X$. axonopodis pv. citri per $\mathrm{ml}$ in the sample for the 52- and 4-h duration experiments, and between temperature and total numbers of $X$. axonopodis pv. citri collected in the 52-h experiments (the first three sample points were not included in this analysis, as they contained large numbers of pre-existing bacteria [26,31]). A test for homogeneity of regression was performed to compare the relationship between the 52- and 4-h regression lines between total number of $X$. axonopodis pv. citri and CFU.

\section{RESULTS}

How long do lesions produce inoculum under a simulated wind-splash event? No $X$. axonopodis pv. citri colonies grew on the control well water that was plated out. The relationship between total number of bacteria collected and the sampling period of $52 \mathrm{~h}$ was best described by

Table 1. Summary of regression statistics used to evaluate model appropriateness to describe temporal dispersal of Xanthomonas axonopodis pv. citri in wind-blown splash from a group of canker-infected trees during a period of $52 \mathrm{~h}$

\begin{tabular}{|c|c|c|c|c|c|}
\hline $\begin{array}{l}\text { Date } \\
(2003)\end{array}$ & Model type $^{a}$ & Intercept (SE) & $\begin{array}{l}\text { Rate parameter } \\
\text { (slope, }[\mathrm{SE}])\end{array}$ & $R^{2 b}$ & Residuals $^{\mathbf{c}}$ \\
\hline \multirow[t]{2}{*}{6 February } & Power & $1.88 \times 10^{6}\left(2.61 \times 10^{5}\right)$ & $-0.6166(0.1649)$ & 0.80 & NP \\
\hline & Exponential & $5.60 \times 10^{5}\left(2.07 \times 10^{5}\right)$ & $0.8140(0.2199)$ & 0.74 & PP \\
\hline \multirow[t]{2}{*}{11 February } & Power & $4.52 \times 10^{5}\left(5.89 \times 10^{4}\right)$ & $-0.8737(0.1859)$ & 0.91 & SP \\
\hline & Exponential & $9.95 \times 10^{4}\left(2.74 \times 10^{4}\right)$ & $1.0924(0.1518)$ & 0.92 & SP \\
\hline \multirow[t]{2}{*}{22 April } & Power & $1.89 \times 10^{6}\left(2.54 \times 10^{5}\right)$ & $-0.7516(0.1752)$ & 0.97 & NP \\
\hline & Exponential & $3.88 \times 10^{5}\left(1.55 \times 10^{5}\right)$ & $1.0515(0.2230)$ & 0.97 & SP \\
\hline
\end{tabular}

a Model types are power model: $y=a x^{b}$, and exponential model: $y=a e^{b / x}$.

${ }^{\mathrm{b}} R^{2}=$ coefficient of determination for the model.

${ }^{c}$ Residual score assessed on linearized models (power model: $\log y=a-b \log x$, exponential model: $\log y=a+(b / x)): \mathrm{NP}=$ no pattern to residuals (random scatter around the prediction line), $\mathrm{SP}=$ slight pattern or curve to scatter, $\mathrm{PP}=$ pronounced pattern or curve to residual scatter. 
a power law model on all 3 days on which the experiment was run. Analysis of the goodness of fit based on coefficients of determination, parameter standard errors, and residual analysis showed that the exponential models were generally less adequate (Table 1). The dummy regression analysis based on a linearized version of the power law model for the three separate days indicated that the slopes $\left(F\right.$ value $_{2,91}=3.65, P$ (probability $)=0.05)$ and intercepts $\left(F_{4,93}=\right.$ $4.45, P=0.05)$ of the regression lines were different (Fig. 2A). However, as the same model type fitted the data from each day, and the ANOVA showed similar relationships for all 3 days, only the detailed results for one experiment (11 February 2003) are shown (Table 2). ANOVA showed significant differences in CFU $X$. axonopodis pv. citri per $\mathrm{ml}(F=10.44, P \leq 0.0001)$ and the total number of bacteria $(F=4.24, P=$ 0.003 ) dispersed at different times, but showed no temporal effect on volume of splash droplets $(F=0.60, P=0.82)$. Sam- pler types collected similar quantities of CFU $X$. axonopodis pv. citri per $\mathrm{ml}(F=$ 2.29, $P=0.14$ ), but panels collected more bacteria overall $(F=108.82, P \leq 0.0001)$ due to the greater volume sampled by the panels $(F=415.24, P \leq 0.0001)$. Bacteria were dispersed continuously over the 52-h period (Fig. 2B), although the CFU $X$. axonopodis pv. citri per $\mathrm{ml}$ of spray collected by the panels decreased rapidly during the first hour and stabilized between 3 and 66 bacteria per $\mathrm{ml}$ from $3 \mathrm{~h}$ onward. The total number of bacteria collected by the panels was $1.48 \times 10^{6}$ at time zero and $6.21 \times 10^{4}$ at $52 \mathrm{~h}\left(4.23 \times 10^{3}\right.$ and 29 bacteria per $\mathrm{ml}$, respectively). The funnel samples showed a similar relationship (Fig. 2C). During the collecting periods, the average wind speed generated by the blowers was between 16 and $20 \mathrm{~m} \mathrm{~s}^{-1}$, and mean temperature within the water-sprayed canopy was 13.7 to $18.0^{\circ} \mathrm{C}$, while the temperature outside the canopy fluctuated between 12.0 and $29.0^{\circ} \mathrm{C}$, depending on the time of day
(Fig. 2D). The surrounding wind speed in the field ranged from 0 to $1.8 \mathrm{~m} \mathrm{~s}^{-1}$, and wind direction ranged from $\mathrm{N}$ to $\mathrm{NE}$ for most of the sampling period. There was a positive correlation between CFU $X$. axonopodis pv. citri per $\mathrm{ml}$ and the total number of $X$. axonopodis pv. citri collected for both panels $(r=0.9131, P<0.001)$ and funnels ( $r=0.9407, P<0.001$ ), but there was no discernable relationship between volume collected and CFU X. axonopodis pv. citri or total $X$. axonopodis pv. citri collected for either sampler. However, correlations between the volume, CFU X. axonopodis pv. citri per $\mathrm{ml}$, and total $X$. axonopodis pv. citri collected by panels and funnels were all positively correlated $(r=0.7703, P<0.001$; $r=0.9481, P<0.001$; and $r=0.9430, P<$ 0.001 , respectively), showing agreement in the sample collected by the two sampler types. There was no correlation between volume sampled, CFU per $\mathrm{ml}$, or total bacteria and wind direction or other weather variables.
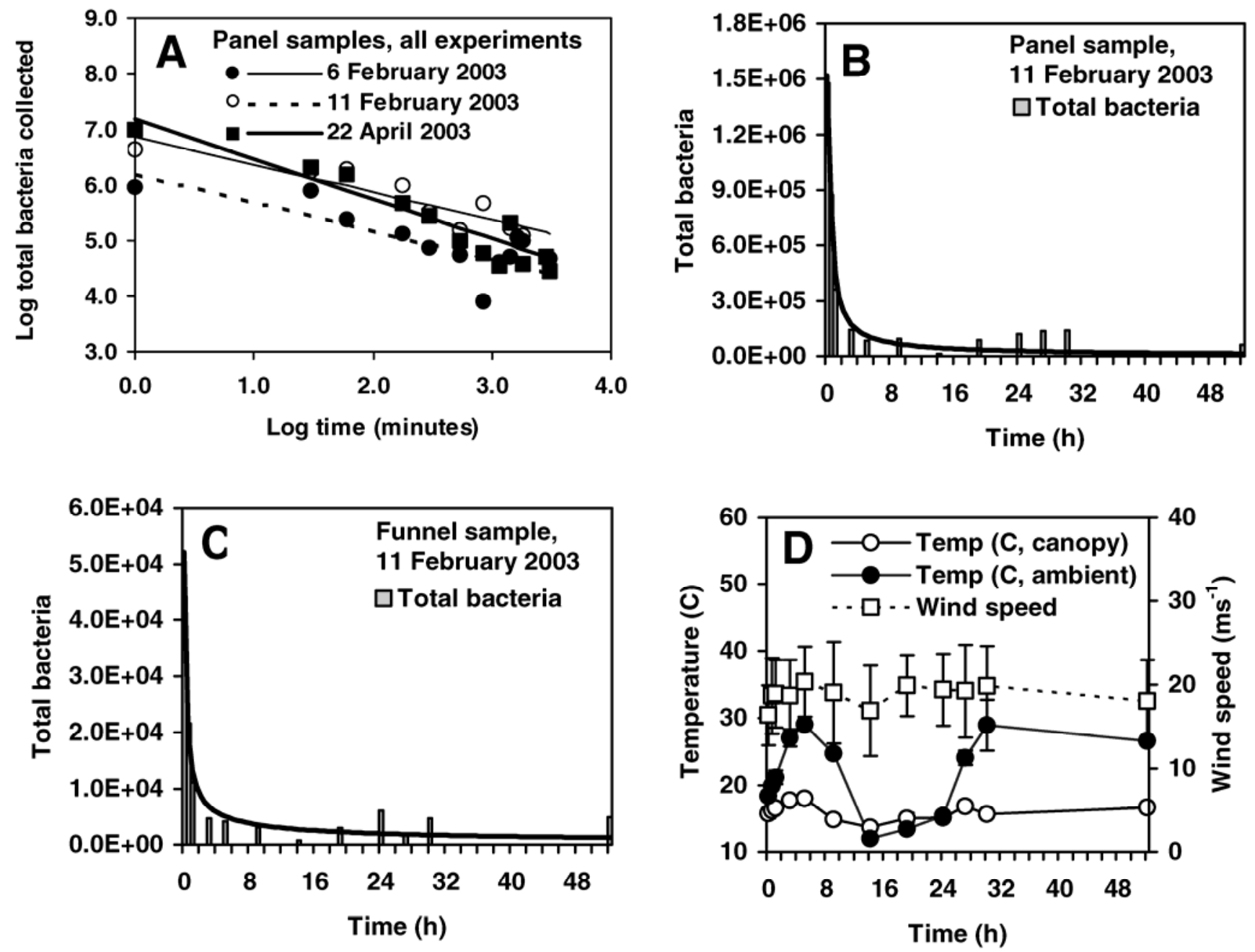

Fig. 2. Relationship between: A, $\log$ of the total number of bacteria $(\log N)$ of Xanthomonas axonopodis pv. citri collected and $\log$ time $(\log T)$ in three experiments performed to investigate the dispersal of bacteria in wind-driven splash over $52 \mathrm{~h}$ (linear regression solutions for $6 \mathrm{February:} \log N=6.86-$ $0.494 \log T\left[R^{2}=0.68\right], 11$ February: $\log N=6.09-0.4299 \log T\left[R^{2}=0.37\right]$, and 22 April $\left.2003: \log N=7.25-0.765 \log T\left[R^{2}=0.62\right]\right) ; \mathbf{B}$, actual total number of $X$. axonopodis pv. citri collected versus time on 11 February 2003 (details of the power law regression solution are shown in Table 1 ); C, actual total number of bacteria collected $(N)$ by funnel samplers and time $\left(T\right.$, inverse power regression solution $N=a T^{b}$ where $a=1.32 \times 10^{4}\left[\right.$ standard error $=1.52 \times 10^{3}$ ] and $b=-0.5972$ [standard error $=0.1222$ ], $\left.R^{2}=0.92\right) ; \mathbf{D}$, corresponding wind and temperature conditions showing standard deviations during the 10-min collecting periods. 
The 4-h duration experiments showed the dynamics early in the process of dispersal. The relationship between total number of bacteria collected and the 4-h sampling period was best described by a power model on all 3 days (Table 3 ). The dummy regression analysis for the three separate days indicated that the slopes $\left(F_{2,135}=2.92, P>0.05\right)$ were not significantly different but that the intercepts were significantly different $\left(F_{2,137}=21.45, P<\right.$ $0.05)$, i.e., initially different quantities of bacteria were dispersed (Fig. 3A). However, as the power law model was consistently best at describing the data on each day, and as the ANOVA showed similar relationships for all three experiments, only the results from a single day are described in detail (15 July 2003, Table 4). The quantity of $X$. axonopodis pv. citri dispersed in wind-blown splash fell dramatically over $4 \mathrm{~h}$ both in the panels downwind (Fig. 3B) and in the funnels (Fig. 3C) at the base of the plants. Sample time did not affect the volumes of spray recovered $(F=1.03, P=0.44)$, although significant differences were found for CFU $X$. axonopodis pv. citri per $\mathrm{ml}(F=9.71, P$ $\leq 0.0001)$ and total bacteria collected $(F=$ $4.30, P \leq 0.0001)$. Not surprisingly, the volume collected by the panels was significantly greater than by the funnels $(F=$ $280.66, P \leq 0.0001)$, as was the total collected $(F=6.21, P=0.0167)$, but the CFU per $\mathrm{ml}$ collected was greater for the funnels than for the panels $(F=46.00, P \leq$ $0.0001)$. At the time of the first sample (0 $\mathrm{min}$ ), the CFU $X$. axonopodis pv. citri per $\mathrm{ml}$ were similar, but after 20 min of dispersal, the funnels consistently collected more bacteria per $\mathrm{ml}$. The concentration (CFU per $\mathrm{ml}$ ) and total bacteria declined immediately after the first 5-min sample and continued to decrease until it stabilized at a fairly consistent quantity after the initial hour of dispersal. The temperatures of the water-splashed canopy (26 to $28^{\circ} \mathrm{C}$ ) and wind speed produced by the blowers (11 to $13 \mathrm{~m} \mathrm{~s}^{-1}$ ) were consistent throughout the collecting periods (Fig. 3D). The temperature outside the canopy ranged from ca. 30 to $35^{\circ} \mathrm{C}$ and the wind speed from 0 to 0.3 $\mathrm{m} \mathrm{s}^{-1}$. Wind direction shifted during the study from the SE-SW to predominantly NE.

For the samples collected by panels, the CFU $X$. axonopodis pv. citri per $\mathrm{ml}$ spray collected was positively correlated with the total $X$. axonopodis pv. citri collected $(r=$ $0.9475, P<0.001)$, but not with the volume of spray collected by the panels (because the volume of spray remains constant while the quantity of bacteria declines). For the samples collected by funnels, the total number of bacteria collected was correlated positively with the volume of spray $(r=0.9263, P<0.001)$ and the CFU per ml spray $(r=0.9263, P<$ 0.001). The CFU per ml collected by the panels was correlated positively with volume collected by the funnels $(r=0.5693$, $P<0.05)$, the CFU per $\mathrm{ml}$ collected by the funnels $(r=0.6263, P<0.01)$, and the total number of bacteria collected by the funnels $(r=0.9707, P<0.001)$. The total number of bacteria collected by the panels was correlated positively with volume collected by the funnels $(r=0.6144, P<$ $0.01)$, the CFU per $\mathrm{ml}$ collected by the funnels $(r=0.5818, P<0.05)$, and the total number of bacteria collected by the funnels $(r=0.9263, P<0.001)$.

For the cumulative total $X$. axonopodis pv. citri collected in the two duration experiments, in the 52 -h study over $70 \%$ of the bacteria were detected in the first hour (Fig. 4A), and in the 4-h experiment over $80 \%$ of the total bacteria collected were detected in the first hour (Fig. 3B). Regression analysis showed the relationship between CFU per $\mathrm{ml}$ and the total number of bacteria collected was linear for panel samples from both the 52- and 4-h experiments (Fig. 3C), and a test for homogeneity of regression confirmed no significant difference. Interestingly, a weakly linear relationship was found between CFU per $\mathrm{ml}$ and ambient temperature during the 52-h experiments on 11 February and 22 April 2003 (there was insufficient data on 6 February). In general, the higher the temperature, the more bacteria were collected (Fig. 5).

How far can inoculum travel during a simulated wind-splash event? The rela-

Table 3. Summary of regression statistics used to evaluate model appropriateness to describe temporal dispersal of Xanthomonas axonopodis pv. citri in wind-blown splash from a group of canker-infected trees during a period of $240 \mathrm{~min}$

\begin{tabular}{llcccc}
\hline Date (2003) & Model type $^{\mathbf{a}}$ & \multicolumn{1}{c}{ Intercept (SE) } & $\begin{array}{c}\text { Rate parameter } \\
\text { (slope, [SE]) }\end{array}$ & $\boldsymbol{R}^{\mathbf{2 b}}$ & Residuals $^{\mathbf{c}}$ \\
\hline 15 July & Power & $1.47 \times 10^{8}\left(6.66 \times 10^{7}\right)$ & $-0.6285(0.1379)$ & 0.85 & $\mathrm{NP}$ \\
& Exponential & $7.37 \times 10^{6}\left(1.89 \times 10^{6}\right)$ & $15.2808(3.5937)$ & 0.82 & $\mathrm{PP}$ \\
29 July & Power & $2.86 \times 10^{7}\left(1.13 \times 10^{7}\right)$ & $-0.4592(0.1107)$ & 0.94 & $\mathrm{NP}$ \\
& Exponential & $3.24 \times 10^{6}\left(6.11 \times 10^{5}\right)$ & $10.97(3.1216)$ & 0.93 & $\mathrm{NP}$ \\
16 September & Power & $3.65 \times 10^{8}\left(6.94 \times 10^{7}\right)$ & $-1.2537(0.0737)$ & 0.98 & $\mathrm{NP}$ \\
& Exponential & $1.41 \times 10^{6}\left(2.19 \times 10^{5}\right)$ & $26.9389(1.6773)$ & 0.97 & $\mathrm{PP}$ \\
\hline
\end{tabular}

a Model types are the power model: $y=a x^{b}$, and exponential model: $y=a e^{b / x}$

${ }^{\mathrm{b}} R^{2}=$ coefficient of determination for the model.

${ }^{c}$ Residual score assessed on linearized models (power model: $\log y=a-b \log x$, exponential model: $\log y=a+(b / x))$ : NP $=$ no pattern to residuals (random scatter around the prediction line), $\mathrm{PP}=$ pronounced pattern or curve to residual scatter.

Table 2. Volume of splash collected, CFU per ml, and total number of Xanthomonas axonopodis pv. citri collected by panels and funnels at different times during a 52-h dispersal period ${ }^{\mathrm{a}}$ (first sample taken at 8:08 A.M. on 11 February 2003)

\begin{tabular}{|c|c|c|c|c|c|c|}
\hline \multirow{2}{*}{$\begin{array}{l}\text { Experiment } \\
\text { duration }(h)\end{array}$} & \multicolumn{2}{|c|}{ Volume $(\mathrm{ml})^{\mathbf{b}}$} & \multicolumn{2}{|c|}{ CFU (bacteria per ml) } & \multicolumn{2}{|c|}{ Total bacteria collected } \\
\hline & Panels $^{c}$ & Funnels & Panels & Funnels & Panels & Funnels \\
\hline 0 & $3.36(2960)$ & $1.76(71)$ & $2.60(423)$ & $2.63(491)$ & $5.95\left(1.48 \times 10^{6}\right)$ & $4.39\left(4.42 \times 10^{4}\right)$ \\
\hline 0.5 & $3.62(4638)$ & $1.89(83)$ & $2.29(193)$ & $2.39(249)$ & $5.90\left(8.75 \times 10^{5}\right)$ & $4.28\left(2.16 \times 10^{4}\right)$ \\
\hline 1 & $3.42(3329)$ & $1.84(75)$ & $1.98(104)$ & $2.14(141)$ & $5.40\left(3.60 \times 10^{5}\right)$ & $3.98\left(1.12 \times 10^{4}\right)$ \\
\hline 3 & $3.43(2978)$ & $1.93(97)$ & $1.70(50)$ & $1.65(46)$ & $5.12\left(1.42 \times 10^{5}\right)$ & $3.58\left(4.69 \times 10^{3}\right)$ \\
\hline 5 & $3.38(2746)$ & $1.91(95)$ & $1.49(31)$ & $1.55(39)$ & $4.87\left(8.59 \times 10^{4}\right)$ & $3.46\left(4.18 \times 10^{3}\right)$ \\
\hline 9 & $3.69(5050)$ & $2.02(113)$ & $1.06(17)$ & $1.29(27)$ & $4.75\left(9.27 \times 10^{4}\right)$ & $3.32\left(3.06 \times 10^{3}\right)$ \\
\hline 14 & $3.43(4201)$ & $1.85(97)$ & $0.67(3)$ & $1.06(8)$ & $3.91\left(1.93 \times 10^{4}\right)$ & $2.82\left(7.78 \times 10^{2}\right)$ \\
\hline 19 & $3.53(4050)$ & $1.92(108)$ & 1.07 (17) & $1.30(29)$ & $4.61\left(8.93 \times 10^{4}\right)$ & $3.22\left(2.98 \times 10^{3}\right)$ \\
\hline 24 & $3.56(4253)$ & $1.95(118)$ & $1.14(26)$ & $1.39(57)$ & $4.70\left(1.22 \times 10^{5}\right)$ & $3.34\left(6.06 \times 10^{3}\right)$ \\
\hline 27 & $3.55(3791)$ & $1.97(121)$ & $1.52(37)$ & $1.15(21)$ & $5.07\left(1.37 \times 10^{5}\right)$ & $3.25\left(1.56 \times 10^{3}\right)$ \\
\hline 30 & $3.43(2870)$ & $1.83(84)$ & $1.56(61)$ & $1.77(61)$ & $4.99\left(1.40 \times 10^{5}\right)$ & $3.61\left(4.68 \times 10^{3}\right)$ \\
\hline 52 & $3.26(2013)$ & $1.66(60)$ & $1.41(29)$ & $1.80(67)$ & $4.67\left(6.21 \times 10^{4}\right)$ & $3.46\left(4.92 \times 10^{3}\right)$ \\
\hline Mean & $3.47(3574)$ & $1.88(94)$ & $1.54(83)$ & $1.68(103)$ & $5.00\left(3.00 \times 10^{5}\right)$ & $3.56\left(9.14 \times 10^{3}\right)$ \\
\hline SED $^{\mathrm{d}}$ time $\times$ sampler & \multirow{2}{*}{\multicolumn{2}{|c|}{$\begin{array}{l}0.192 \\
0.055\end{array}$}} & \multirow{2}{*}{\multicolumn{2}{|c|}{$\begin{array}{l}0.215 \\
0.065\end{array}$}} & \multirow{2}{*}{\multicolumn{2}{|c|}{$\begin{array}{l}0.328 \\
0.099\end{array}$}} \\
\hline SED sampler means & & & & & & \\
\hline
\end{tabular}

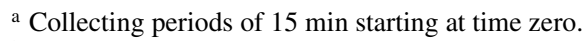

${ }^{\mathrm{b}}$ Log-transformed values are shown with nontransformed values in parentheses.

c Panels and funnels were situated together $1 \mathrm{~m}$ downwind from the source of inoculum (Fig. 1).

d $\mathrm{SED}=$ standard error of the difference between means.
} 
tionship between total number of bacteria collected and distance was best described by a power law model (Table 5), although dummy regression analysis indicated there were significant differences among the slopes and intercepts on the 4 days on which the experiment was repeated $\left(F_{3,73}=\right.$ 2.68, $P<0.05$ and $F_{3,76}=10.19, P<0.05$, respectively, Fig. 6A). The power law relationship between total bacteria collected and dispersal distance is illustrated with the data from 18 September 2003 (Fig. 6B). ANOVA (Table 6) showed that volume was affected by distance from the source of inoculum $(F=94.49, P<$ $0.0001)$, and as expected, sampler type affected volume collected $(F=10.29, P=$ $0.0044)$, with the panels collecting more than the funnels closer to the plants $(3,703$ $\mathrm{ml}$ versus $60 \mathrm{ml}$ at $1 \mathrm{~m}$, respectively); but at $6 \mathrm{~m}$, although spray was observed on the panels, there was an insufficient volume of spray deposited on the panel surface to collect in the collection vessel. ANOVA showed significant differences due to dis- tance for both the number of bacteria collected per $\mathrm{m}^{2}$ panel surface $(F=18.67, P<$ $0.0001)$ and the total bacteria collected $(F$ $=9.86, P<0.0001)$. Funnels located on the ground collected relatively more bacteria on a per $\mathrm{m}^{2}$ surface area basis than did the vertical panels $(F=35.81, P<0.0001)$, although there was no difference in mean total bacteria collected by the different samplers at different distances $(F=0.01, P$ $<0.9385)$. Interestingly, where sufficient volume was collected, the concentration of bacteria (CFU per ml) was greatest for the funnel at all distances (27-fold more concentrated in funnels under the trees than on panels at $1 \mathrm{~m}$ distance, although the difference at $4 \mathrm{~m}$ was only twofold). Wind speed rapidly declined with distance, from 19.5 $\mathrm{m} \mathrm{s}^{-1}$ upwind of the trees to $2.8 \mathrm{~m} \mathrm{~s}^{-1}$ immediately downwind, and by $4 \mathrm{~m}$ distant, wind speed was not detectably different from surrounding conditions. Wind direction was initially from the N-NE and shifted to the ENE-ESE, but it had no detectable effect on the sample, perhaps because surrounding wind speeds were low ( 0 to $0.5 \mathrm{~m} \mathrm{~s}^{-1}$ ). The cumulative total bacteria collected over distance for both panels and funnels show that $>90 \%$ were collected at $1 \mathrm{~m}$ from the source (Fig. 7A). The quantity of bacteria collected was different with each replicate of the experiment-the first replicate collected most, followed by diminishing quantities of bacteria in the second and third replicates (Fig. 7B) - although the volume of droplets collected remained fairly consistent between replicates and demonstrated the rapid drop in quantity of bacteria produced by lesions observed in the duration experiments as the same trees were used and replicates were repeated one after the other, resulting in a decline in available bacteria.

The volume of spray collected and the total CFU of $X$. axonopodis pv. citri collected were correlated positively for the panel $(r=0.9382, P<0.001)$ and funnel $(r$ $=0.9666, P<0.001)$ samples. The volume of spray collected by the panel was corre-
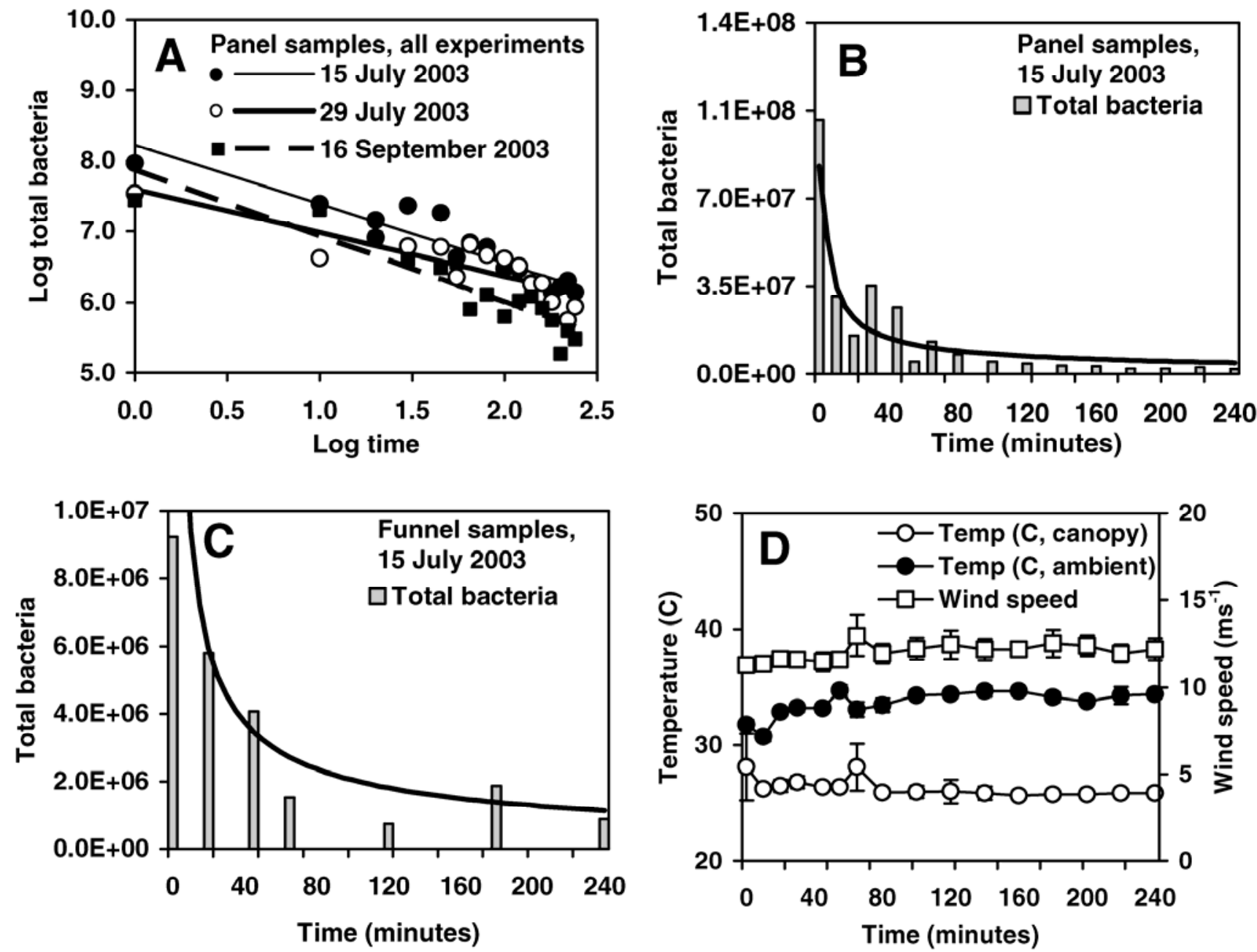

Fig. 3. Relationship between: A, $\log$ of the total number of bacteria $(\log N)$ of Xanthomonas axonopodis pv. citri collected by panel samplers and $\log$ time $(\log T)$ in three experiments performed to investigate the dispersal of bacteria in wind-driven splash over 240 min (linear regression solutions for 15 July: $\log N=8.22-0.8336 \log T\left[R^{2}=0.54\right], 29 \mathrm{July}: \log N=7.60-0.6141 \log T\left[R^{2}=0.58\right]$, and 11 September $\left.2003: \log N=7.87-0.9320 \log T\left[R^{2}=0.73\right]\right) ; \mathbf{B}$, actual total number of bacteria collected $(\mathrm{N})$ by panel samplers and time $(T)$ on 15 July (details of the power law regression solution are shown in Table 3 ); C, actual total number of bacteria collected $(N)$ by funnel samplers and time $\left(T\right.$, inverse power regression solution $N=a T^{b}$ where $a=4.35 \times 10^{7}$ [standard error $\left.=2.35 \times 10^{7}\right]$ and $b=-0.6647$ [standard error $\left.\left.=0.1531\right], R^{2}=0.96\right)$. D, Corresponding wind and temperature conditions during the 5-min collecting periods are shown with standard deviations. 
lated positively with volume of spray collected by the funnels $(r=0.9863, P<$ 0.001 ), and with the total number of bacteria collected by the funnels $(r=0.9555, P$ $<0.001)$. The total number of bacteria collected by the panels was positively correlated with volume of spray collected by the funnels $(r=0.9270, P<0.01)$ and total number of bacteria collected by the funnels $(r=0.9884, P<0.001)$.

\section{DISCUSSION}

The greatest quantity of bacteria was dispersed in the first few minutes after initiation of a wind/splash event, after which the quantity fell dramatically over the first hour. In all experiments (including the consecutive replicates of the distance experiment), the quantity of bacteria in wind-blown spray declined, confirming previous observations $(27,32)$ on the effect of rain alone on the dynamics of populations of $X$. axonopodis pv. citri during a dispersal event. The numbers of bacteria dispersed by wind and splash were initially $10^{4}$ to $10^{5}$ per ml, which declined to $10^{2}$ to $10^{3}$ after the first hour. This is less than the $10^{7}$ bacteria per $\mathrm{ml}$ initially dispersed as observed by Pruvost et al. (27), but is similar to other reports of $10^{2}$ to $10^{5}$ and $10^{1}$ to $10^{3}$ bacteria per $\mathrm{ml}$ during the first hour and thereafter, respectively (32). The host plant size, age of lesions, severity of infection, rainfall intensity, and nature of the splash likely affects the quantity of bacteria dispersed and could explain much of the difference in numbers of bacteria dispersed in different studies.

The results confirm that $X$. axonopodis pv. citri is immediately and readily dispersed by wind/rain events (29), and the dynamics of dispersal over time were well
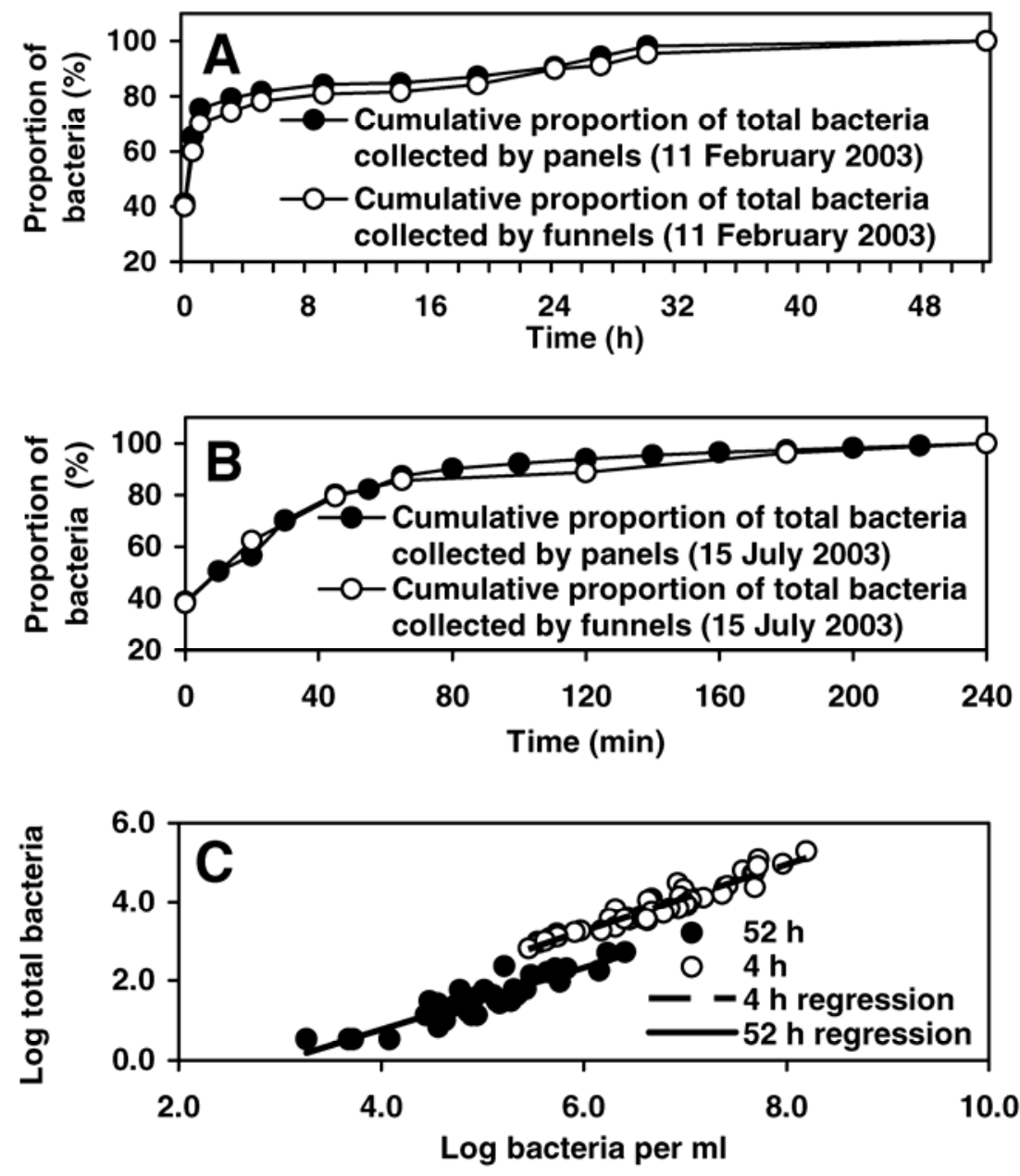

Fig. 4. Cumulative total bacteria collected A, over a period of $52 \mathrm{~h}$ by panels (11 February 2003) and, B, over a period of $4 \mathrm{~h}$ by panels and funnels (15 July 2003) and, C, the relationship between log CFU of Xanthomonas axonopodis pv. citri per $\mathrm{ml}(\log N)$ and $\log$ total bacteria collected $(\log T)$ when winddriven splash was continuously applied to a group of canker-infected plants over 4 or $52 \mathrm{~h}$ as collected by panels (linear regression solutions for 11 February [52 h]: $\log N=-1.7991+0.8429 \log T\left[R^{2}=0.91\right]$ and 15 July $\left.2003[4 \mathrm{~h}]: \log N=-2.35+0.7783 \log T\left[R^{2}=0.83\right]\right)$.

Table 4. Volume of splash collected, CFU per ml, and total number of Xanthomonas axonopodis pv. citri collected by panels and funnels at different times during a 240-min dispersal period (15 July 2003)

\begin{tabular}{|c|c|c|c|c|c|c|}
\hline \multirow{2}{*}{$\begin{array}{l}\text { Experiment } \\
\text { duration }^{\text {a }}(\mathrm{min})\end{array}$} & \multicolumn{2}{|c|}{ Volume $(\mathrm{ml})^{\mathbf{b}}$} & \multicolumn{2}{|c|}{ CFU (bacteria per ml) } & \multicolumn{2}{|c|}{ Total bacteria collected } \\
\hline & Panels $^{c}$ & Funnels & Panels & Funnels & Panels & Funnels \\
\hline 0 & $2.85(755)$ & $2.03(122)$ & $5.11\left(1.36 \times 10^{5}\right)$ & $5.14\left(1.39 \times 10^{5}\right)$ & $7.96\left(1.01 \times 10^{8}\right)$ & $7.44\left(2.77 \times 10^{3}\right)$ \\
\hline 10 & $2.73(600)$ & & $4.66\left(4.79 \times 10^{4}\right)$ & & $7.39\left(3.09 \times 10^{7}\right)$ & \\
\hline 20 & $2.88(815)$ & $1.69(50)$ & $4.27\left(1.96 \times 10^{4}\right)$ & $5.05\left(1.14 \times 10^{5}\right)$ & $7.16\left(1.56 \times 10^{7}\right)$ & $6.73\left(5.80 \times 10^{3}\right)$ \\
\hline 30 & $2.77(623)$ & & $4.59\left(5.04 \times 10^{4}\right)$ & & $7.36\left(3.53 \times 10^{7}\right)$ & \\
\hline 45 & $3.01(1220)$ & $1.96(96)$ & $4.25\left(1.92 \times 10^{4}\right)$ & $4.64\left(4.56 \times 10^{4}\right)$ & $7.26\left(2.67 \times 10^{7}\right)$ & $6.60\left(4.07 \times 10^{3}\right)$ \\
\hline 55 & $2.64(453)$ & & $4.00\left(1.04 \times 10^{4}\right)$ & & $6.63\left(5.10 \times 10^{6}\right)$ & \\
\hline 65 & $2.98(952)$ & $1.83(72)$ & $3.86\left(1.02 \times 10^{4}\right)$ & $4.50\left(3.15 \times 10^{4}\right)$ & $6.84\left(1.31 \times 10^{7}\right)$ & $6.32\left(2.30 \times 10^{3}\right)$ \\
\hline 80 & $2.95(952)$ & & $3.84\left(7.58 \times 10^{3}\right)$ & & $6.78\left(7.97 \times 10^{6}\right)$ & \\
\hline 100 & $2.84(777)$ & & $3.63\left(5.37 \times 10^{3}\right)$ & & $6.47\left(5.15 \times 10^{6}\right)$ & \\
\hline 120 & $2.91(883)$ & $1.53(34)$ & $3.56\left(4.17 \times 10^{3}\right)$ & $4.46\left(3.37 \times 10^{4}\right)$ & $\left.6.474 .36 \times 10^{6}\right)$ & $5.93\left(1.10 \times 10^{3}\right)$ \\
\hline 140 & $2.80(697)$ & & $3.47\left(3.87 \times 10^{3}\right)$ & & $6.27\left(3.34 \times 10^{6}\right)$ & \\
\hline 160 & $2.86(800)$ & & $3.41\left(3.20 \times 10^{3}\right)$ & & $6.27\left(3.12 \times 10^{6}\right)$ & \\
\hline 180 & $2.91(883)$ & $1.92(95)$ & $3.23\left(2.06 \times 10^{3}\right)$ & $4.26\left(2.02 \times 10^{4}\right)$ & $6.13\left(2.20 \times 10^{6}\right)$ & $6.19\left(1.86 \times 10^{3}\right)$ \\
\hline 200 & $2.81(697)$ & & $3.41\left(2.87 \times 10^{3}\right)$ & & $6.22\left(2.26 \times 10^{6}\right)$ & \\
\hline 220 & $2.88(823)$ & & $3.43\left(2.98 \times 10^{3}\right)$ & & $6.31\left(2.78 \times 10^{6}\right)$ & \\
\hline 240 & $2.86(793)$ & $1.65(45)$ & $3.28\left(2.18 \times 10^{3}\right)$ & $4.28\left(2.00 \times 10^{4}\right)$ & $6.14\left(2.05 \times 10^{6}\right)$ & $5.94\left(8.75 \times 10^{3}\right)$ \\
\hline Mean & $2.86(795.2)$ & $1.80(73.5)$ & $3.87\left(2.05 \times 10^{4}\right)$ & $4.61\left(5.76 \times 10^{4}\right)$ & $6.73\left(1.63 \times 10^{7}\right)$ & $5.93\left(3.44 \times 10^{3}\right)$ \\
\hline SED $^{\mathrm{d}}$ time $\times$ sampler & \multicolumn{2}{|c|}{0.122} & \multicolumn{2}{|c|}{0.192} & \multicolumn{2}{|c|}{0.425} \\
\hline SED sampler means & \multicolumn{2}{|c|}{0.046} & \multicolumn{2}{|c|}{0.071} & \multicolumn{2}{|c|}{0.111} \\
\hline
\end{tabular}

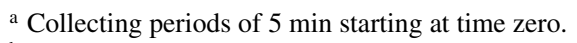

${ }^{\mathrm{b}}$ Log-transformed values are shown with nontransformed values in parentheses.

${ }^{c}$ Panels were $1 \mathrm{~m}$ downwind from trees, funnels were directly under trees.

${ }^{\mathrm{d}} \mathrm{SED}=$ standard error of the difference between means. 
described by the power law model, which has previously been used to describe the distance that pathogens are dispersed from their host by wind or splash $(1,7,20,25)$. It should be stressed that this is a model system, and in a grove situation the quantity of bacteria sampled is likely dependent on a number of factors, including disease incidence and severity, lesion age, rainfall intensity, plant size and architecture, and wind speed. However, we had fairly constant conditions of wind and splash, and the rapid temporal decline in quantity of bacteria supported previous observations of a large resident population in lesions prior to a dispersal stimulus (27), followed by a prolonged period of dispersal at a

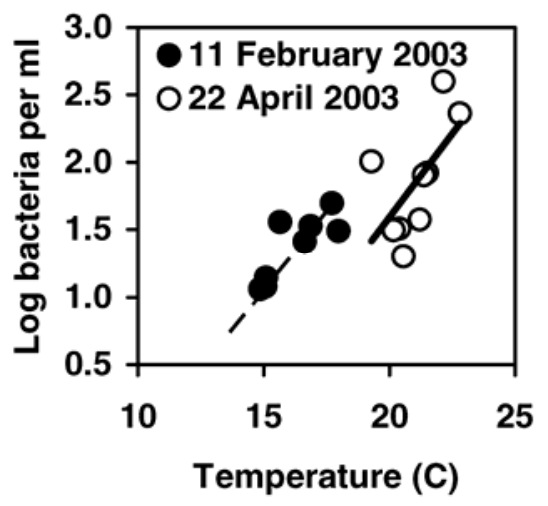

Fig. 5. Relationship between $\log \mathrm{CFU}$ of Xanthomonas axonopodis pv. citri per $\mathrm{ml}(\log N)$ and temperature $(T)$ when wind-driven splash was applied continuously to a group of cankerinfected plants over $52 \mathrm{~h}$ on 11 February and 22 April 2003 (linear regression solutions for 11 February: $\log N=-2.7913+0.2596 T\left[R^{2}=\right.$ 0.82], and 22 April 2003: $\log N=-3.3333+$ $\left.0.2463 T\left[R^{2}=0.38\right]\right)$. Only data from hour 3 of the experiment onward are included in regression analysis to avoid the large initial dispersal event of bacteria already in the lesion. constant rate, which might equal the ability of the bacteria to reproduce, as the intralesion crop of bacteria does not appear to decrease after this time $(27,32)$. The immediate release of high concentrations of bacterial inoculum is advantageous to maximize dispersal of plant bacteria in tropical/subtropical climates where rain showers are often of short duration, intense, and accompanied by strong, gusting wind.

Droplets of water containing citrus canker bacteria were effectively entrained in wind and collected at least $12 \mathrm{~m}$ downwind from the inoculum source. We observed $4.72 \times 10^{3}$ bacteria per $\mathrm{m}^{2}$ at $12 \mathrm{~m}$, corroborating the finding of Stall et al. (31) that bacteria may be dispersed many meters from the source. There was a sharp reduction in wind speed and the resulting dispersal gradient was steep, which is true for most splash-dispersed pathogens $(7,9,24)$, and thus no visible spray droplets were captured on panels beyond $6 \mathrm{~m}$, so aerosol-size droplets likely impacted on panels at 10 or $12 \mathrm{~m}$. In turbulent conditions, power law models have been appropriate for describing gradients of dispersal $(1,7,9)$. Power law models consistently described the gradients of dispersal (or deposition) of $X$. axonopodis pv. citri. However, the model system used mechanical blowers in still air, and this resulted in a steep wind gradient. In real storm conditions, the wind would likely be turbulent but would have continuity in space as the entire air mass of a region passes by infected plants. Thus the splash removed from the foliage would be dispersed further by the wind, possibly resulting in a shallower gradient. In addition to the wind, tree size, canopy architecture, disease severity, and lesion age would also likely affect the quantity of bacteria dispersed.

Funnels placed at ground level sampled a greater concentration of bacteria than panels. The reason for this is not clear but may be related to the different orientation

Table 5. Summary of regression statistics to evaluate model appropriateness to describe dispersal of Xanthomonas axonopodis pv. citri in wind-blown splash from a group of canker-infected trees over a distance of $12 \mathrm{~m}$ on four different dates

\begin{tabular}{|c|c|c|c|c|c|}
\hline Date (2003) & Model type $^{a}$ & Intercept (SE) & $\begin{array}{l}\text { Rate parameter } \\
\text { (slope, }(\mathrm{SE}))\end{array}$ & $R^{2 b}$ & Residuals $^{\mathrm{c}}$ \\
\hline \multirow[t]{2}{*}{4 February } & Power & $1.50 \times 10^{7}\left(2.53 \times 10^{6}\right)$ & $-1.8454(0.7381)$ & 0.60 & SP \\
\hline & Exponential & $5.36 \times 10^{5}\left(6.31 \times 10^{5}\right)$ & $3.3345(1.2030)$ & 0.58 & PP \\
\hline \multirow[t]{2}{*}{18 April } & Power & $4.57 \times 10^{6}\left(5.67 \times 10^{5}\right)$ & $-1.9227(0.5865)$ & 0.76 & NP \\
\hline & Exponential & $1.59 \times 10^{5}\left(1.49 \times 10^{5}\right)$ & $3.3602(0.9596)$ & 0.74 & PP \\
\hline \multirow[t]{2}{*}{26 June } & Power & $1.08 \times 10^{6}\left(1.88 \times 10^{5}\right)$ & $-1.5430(0.5573)$ & 0.59 & NP \\
\hline & Exponential & $5.72 \times 10^{4}\left(5.44 \times 10^{4}\right)$ & $2.9378(0.9842)$ & 0.55 & PP \\
\hline \multirow[t]{2}{*}{18 September } & Power & $4.93 \times 10^{6}\left(3.79 \times 10^{5}\right)$ & $-3.5526(1.2860)$ & 0.88 & SP \\
\hline & Exponential & $2.58 \times 10^{4}\left(4.59 \times 10^{4}\right)$ & $5.2913(1.8514)$ & 0.88 & PP \\
\hline
\end{tabular}

${ }^{a}$ Model types are the power model: $y=a x^{b}$, and exponential model: $y=a e^{b / x}$.

${ }^{\mathrm{b}} R^{2}=$ coefficient of determination for the model.

${ }^{\mathrm{c}}$ Residual score assessed on linearized models (power model: $\log y=a-b \log x$, exponential model: $\log y=a+(b / x)): \mathrm{NP}=$ no pattern to residuals (random scatter around the prediction line), $\mathrm{SP}=$

slight pattern or curve to scatter, $\mathrm{PP}=$ pronounced pattern or curve to residual scatter.
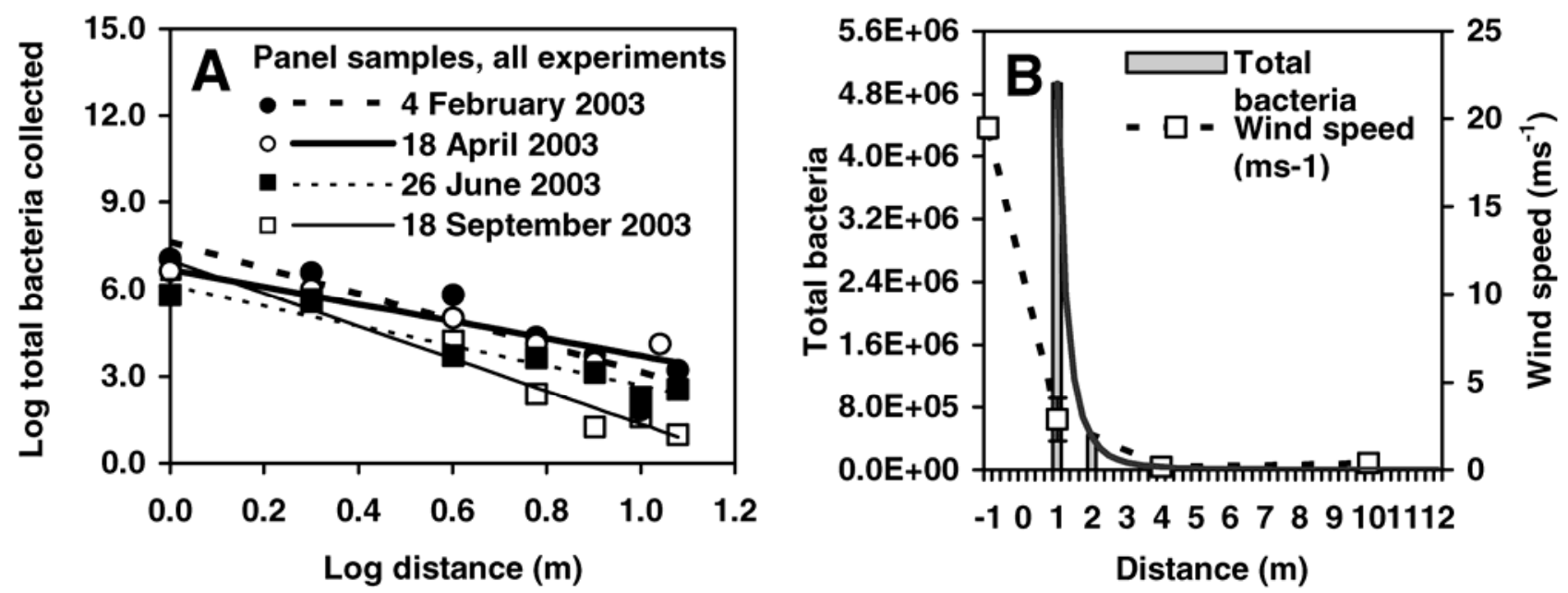

Fig. 6. Relationship between: A, total number of bacteria $(\log N)$ of Xanthomonas axonopodis pv. citri collected by panel samplers and distance $(\log D)$ from inoculum source in four experiments performed to investigate the dispersal of bacteria in wind-driven splash (linear regression solutions for 4 February: $\log N$ $=7.63-4.480 \log D\left[R^{2}=0.76\right], 18$ April: $\log N=6.68-2.978 \log D\left[R^{2}=0.87\right], 26$ June: $\log N=6.11-3.437 \log D\left[R^{2}=0.72\right]$, and 18 September 2003: $\log N$ $\left.=6.99-5.639 \log D\left[R^{2}=0.77\right]\right) ; \mathbf{B}$, actual total number of bacteria collected $(N)$ by panel samplers and distance $(D)$ on 18 September 2003 (details of power law regression solution are shown in Table 5). Wind speed data with standard deviations are shown at the four points where it was recorded $(-1,+1,+4$, and $+10 \mathrm{~m}$ downwind from the inoculum source). 
and heights at which the samplers were positioned. Perhaps funnels did not sample horizontally moving splash, some of which could be inoculum-free. Panels were directly in the downwind plume of spray and may have caught inoculum-free splash that blew through the trees. Funnel samples from under the trees tended to have higher concentrations of bacteria and also greater contamination than any of the panel samples. Nonetheless, the overall trend of decreasing numbers of bacteria with duration and distance was similar to that of the panels, and indeed the samples collected by the panels at ca. $1 \mathrm{~m}$ height and the funnels at ground level were correlated in all experiments.

Lesion age, among other factors, can affect the quantity of bacteria dispersed $(4,27,32)$. In the 11 February 2003 experiment of 52-h, a group of plants with older lesions $(6$ months +$)$ was used. The first sample collected at time zero contained 4.2 $\times 10^{2}$ bacteria per $\mathrm{ml}$-much less than from plants with younger lesions used later in the season. This also suggests that the potential remains for dispersal even when conditions are less favorable. Temperature influences the capacity of $X$. axonopodis pv. citri to grow (26), and we found a positive relationship between temperature and number of bacteria collected. The preferred temperature for growth of $X$. axonopodis pv. citri is between 20 and $30^{\circ} \mathrm{C}$ (26), and the canopy temperatures were largely dependent on the temperature of the water used as the spray source. There was a close correlation between the concentration of bacteria (CFU $X$. axonopodis pv. citri per $\mathrm{ml}$ ) and the total number of
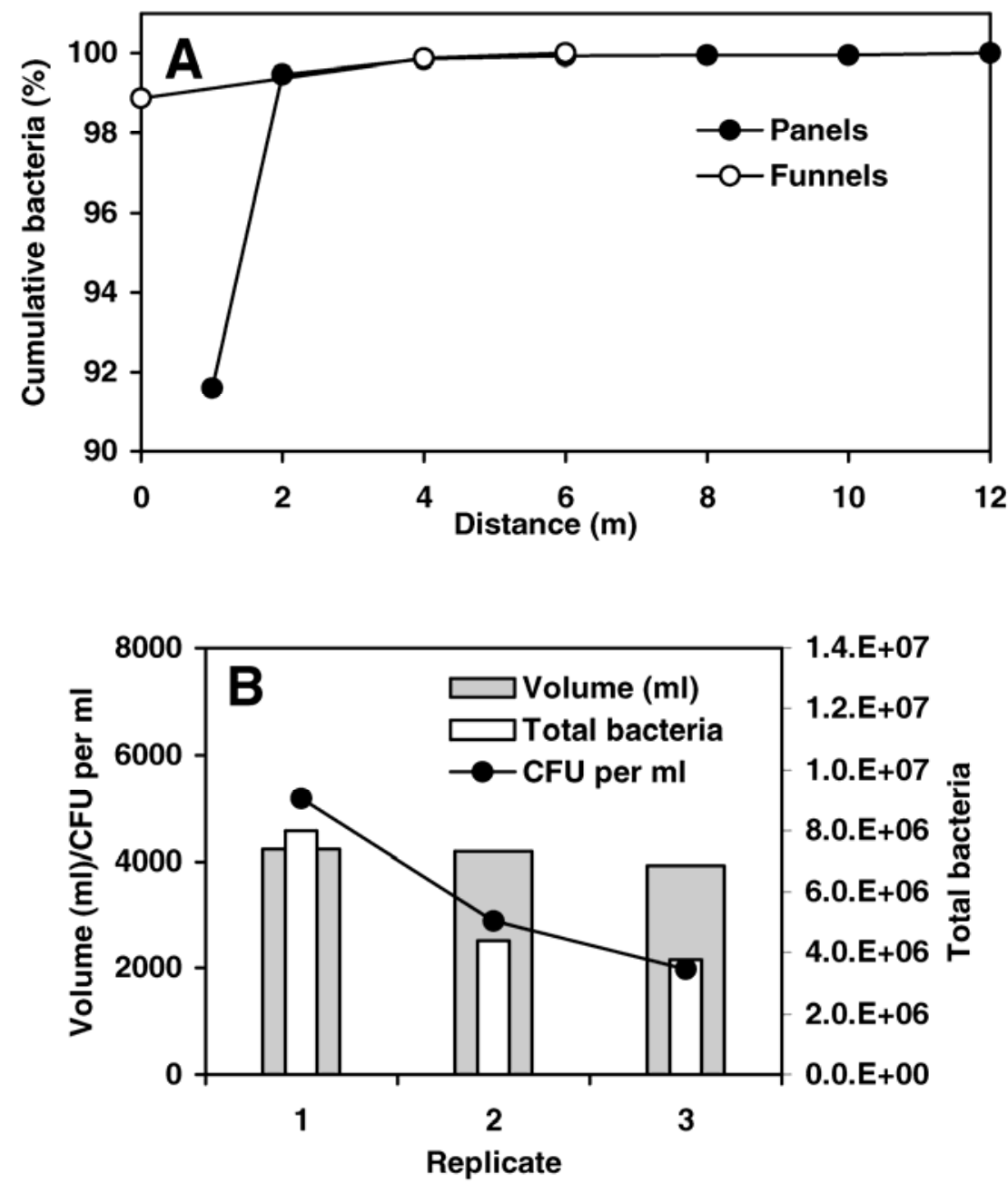

Fig. 7. Effect of $\mathbf{A}$, distance $(D)$ on cumulative total bacteria of Xanthomonas axonopodis pv. citri collected $(N)$ by panels and funnels different distances from a source of inoculum, and $\mathbf{B}$, replicate on volume of splash, cumulative total bacteria, and CFU per ml collected on 18 September 2003.

Table 6. Volume of wind-blown splash collected, CFU bacteria per ml, and total number of Xanthomonas axonopodis pv. citri collected by panels and funnels at different distances downwind from a source of inoculum (18 September 2001)

\begin{tabular}{|c|c|c|c|c|c|c|c|c|}
\hline \multirow[b]{2}{*}{ Distance $(\mathbf{m})^{\mathbf{a}}$} & \multicolumn{2}{|c|}{ Volume $(\mathbf{m l})^{\mathbf{b}}$} & \multicolumn{2}{|c|}{ Bacteria per $\mathbf{m l}^{\mathbf{b}}$} & \multicolumn{2}{|c|}{ Bacteria per $\mathbf{m}^{2 \mathbf{b}}$} & \multicolumn{2}{|c|}{ Total bacteria collected ${ }^{b}$} \\
\hline & Panels & Funnels $^{c}$ & Panels & Funnels & Panels & Funnels & Panels & Funnels \\
\hline $1 \mathrm{P}(0 \mathrm{~F})^{\mathrm{d}}$ & $\begin{array}{c}3.57 \\
(3703)\end{array}$ & $\begin{array}{l}1.76 \\
(60)\end{array}$ & $\begin{array}{c}3.10 \\
\left(1.33 \times 10^{3}\right)\end{array}$ & $\begin{array}{c}4.11 \\
\left(3.59 \times 10^{4}\right)\end{array}$ & $\begin{array}{c}7.60 \\
\left(4.19 \times 10^{7}\right)\end{array}$ & $\begin{array}{c}8.92 \\
\left(2.86 \times 10^{9}\right)\end{array}$ & $\begin{array}{c}6.67 \\
\left(4.93 \times 10^{6}\right)\end{array}$ & $\begin{array}{c}5.88 \\
\left(2.57 \times 10^{6}\right)\end{array}$ \\
\hline 2 & $\begin{array}{c}2.58 \\
(397)\end{array}$ & & $\begin{array}{c}2.99 \\
\left(1.01 \times 10^{3}\right)\end{array}$ & & $\begin{array}{c}6.50 \\
\left(3.60 \times 10^{6}\right)\end{array}$ & & $\begin{array}{c}5.57 \\
\left(4.23 \times 10^{5}\right)\end{array}$ & \\
\hline 4 & $\begin{array}{l}0.85 \\
(13)\end{array}$ & $\begin{array}{l}0.99 \\
(10)\end{array}$ & $\begin{array}{c}2.05 \\
\left(8.9 \times 10^{2}\right)\end{array}$ & $\begin{array}{c}3.15 \\
\left(1.97 \times 10^{3}\right)\end{array}$ & $\begin{array}{c}5.15 \\
\left(1.81 \times 10^{5}\right)\end{array}$ & $\begin{array}{c}7.24 \\
\left(2.33 \times 10^{7}\right)\end{array}$ & $\begin{array}{c}4.22 \\
\left(2.13 \times 10^{4}\right)\end{array}$ & $\begin{array}{c}4.32 \\
\left(2.55 \times 10^{4}\right)\end{array}$ \\
\hline 6 & $\begin{array}{c}0 \\
(0)\end{array}$ & $\begin{array}{l}0.51 \\
(4)\end{array}$ & $0^{\mathrm{e}}$ & $\begin{array}{c}2.89 \\
\left(8.83 \times 10^{2}\right)\end{array}$ & $\begin{array}{c}3.00 \\
\left(2.84 \times 10^{4}\right)\end{array}$ & $\begin{array}{c}6.39 \\
\left(3.56 \times 10^{7}\right)\end{array}$ & $\begin{array}{c}2.38 \\
\left(3.33 \times 10^{3}\right)\end{array}$ & $\begin{array}{c}3.35 \\
\left(3.24 \times 10^{3}\right)\end{array}$ \\
\hline 8 & $\begin{array}{c}0 \\
(0)\end{array}$ & & & & $\begin{array}{c}1.54 \\
\left(1.42 \times 10^{4}\right)\end{array}$ & & $\begin{array}{c}1.23 \\
\left(1.67 \times 10^{3}\right)\end{array}$ & \\
\hline 10 & $\begin{array}{c}0 \\
(0)\end{array}$ & & & & $\begin{array}{c}2.20 \\
\left(1.42 \times 10^{3}\right)\end{array}$ & & $\begin{array}{c}1.58 \\
(167)\end{array}$ & \\
\hline 12 & $\begin{array}{c}0 \\
(0)\end{array}$ & & & & $\begin{array}{c}1.38 \\
\left(4.72 \times 10^{3}\right)\end{array}$ & & $\begin{array}{c}1.28 \\
\left(2.22 \times 10^{3}\right)\end{array}$ & \\
\hline Mean & $\begin{array}{c}1.00 \\
(587.6)\end{array}$ & $\begin{array}{l}1.09 \\
(24.5)\end{array}$ & $\begin{array}{c}1.72 \\
\left(7.21 \times 10^{2}\right)\end{array}$ & $\begin{array}{c}3.38 \\
\left(1.29 \times 10^{4}\right)\end{array}$ & $\begin{array}{c}3.91 \\
\left(6.54 \times 10^{6}\right)\end{array}$ & $\begin{array}{c}7.51 \\
\left(9.60 \times 10^{8}\right)\end{array}$ & $\begin{array}{c}3.28 \\
\left(7.69 \times 10^{5}\right)\end{array}$ & $\begin{array}{c}4.52 \\
\left(8.66 \times 10^{5}\right)\end{array}$ \\
\hline $\begin{array}{l}\text { SED }^{f} \text { distance } \\
\times \text { sampler }\end{array}$ & \multicolumn{2}{|c|}{0.187} & \multicolumn{2}{|c|}{0.439} & \multicolumn{2}{|c|}{0.894} & \multicolumn{2}{|c|}{0.520} \\
\hline $\begin{array}{l}\text { SED sampler } \\
\text { means }\end{array}$ & \multicolumn{2}{|c|}{0.108} & \multicolumn{2}{|c|}{0.254} & \multicolumn{2}{|c|}{0.369} & \multicolumn{2}{|c|}{0.300} \\
\hline
\end{tabular}

a Collecting periods of $10 \mathrm{~min}$.

${ }^{\mathrm{b}}$ Log-transformed values are shown with nontransformed values in parentheses.

${ }^{\mathrm{c}}$ No funnel samples were taken at $2,8,10$, or $12 \mathrm{~m}$.

${ }^{\mathrm{d}}$ Panels were $1 \mathrm{~m}$ downwind, funnels were under the trees.

e No sample was collected by the panels at $6 \mathrm{~m}$, so CFU per $\mathrm{ml}$ could not be established, although panel washes did yield bacteria.

${ }^{\mathrm{f}} \mathrm{SED}=$ standard error of the difference between means. 
bacteria collected. The volume sampled did not change significantly between sample times during the dispersal duration experiments, or at individual collection locations in the dispersal distance experiment, so the reduction or increase in quantity of bacteria is due to the quantity released into the water for dispersal rather than to changes in the volume of water collected affecting bacterial concentration.

During rainstorms, wind might be predominantly from a single direction, but powerful turbulence, gusts, updrafts, and downdrafts would be a likely component associated with such storms and could carry inoculum substantial distances and enhance deposition. The spatial distribution of citrus canker suggests that it can be dispersed up to several kilometers in rain storms $(3,11,14)$, and recent analysis shows the risk of infection $1,900 \mathrm{ft}(570$ $\mathrm{m}$ ), and further, from an inoculum source (17). The results illustrate the combined action of rain splash and wind on the dispersal of citrus canker commented on by previous authors $(6,17,29,31)$.

Knowledge and understanding of the effect of wind and rain droplet splash on dispersal of $X$. axonopodis pv. citri not only provides more information on the pathogen epidemiology but also gives us a rational basis for disease management strategy, including choice of windbreaks (18) and disease eradication programs $(15,17)$. Powerful storms with high wind speeds occur frequently during the summer in Florida and other tropical wet citrusgrowing regions, and tropical storms and hurricanes are not atypical along the Florida peninsula $(11,14)$. These events likely disperse bacteria, but the relationship between the dispersal forces of rain, rain intensity, droplet size, dilution, dispersal, and infection have not been clarified. Some of these aspects are the subjects of ongoing study both in the field and using a wind tunnel/rain-generating facility.

\section{ACKNOWLEDGMENTS}

We acknowledge the contribution of José Renteria (USDA-APHIS, Edinburg, TX), who constructed the panels and blower/spray system, and Russell Sheetz (USDA-APHIS, Edinburg, TX) and Tara Zacharakis (Florida International University, Miami), who provided assistance in performing the experiments.

\section{LITERATURE CITED}

1. Aylor, D. E. 1990. The role of intermittent wind in the dispersal of fungal pathogens.
Annu. Rev. Phytopathol. 28:73-92.

2. Butterworth, J., and McCartney, H. A. 1991. The dispersal of bacteria from leaf surfaces by water splash. J. Appl. Bacteriol. 7:484-496.

3. Danos, E., Berger, R. D., and Stall, R. E. 1984. Temporal and spatial spread of citrus canker within groves. Phytopathology 74:904-908.

4. Egel, D. S., Graham, J. H., and Riley, T. D. 1991. Population dynamics of strains of Xanthomonas campestris differing in aggressiveness on Swingle citrumelo and grapefruit. Phytopathology 81:666-671.

5. Faulwetter, R. C. 1917. Dissemination of the angular leaf spot of cotton. J. Agric. Res. 8:457-475.

6. Faulwetter, R. C. 1917. Wind-blown rain, a factor in disease dissemination. J. Agric. Res. 10:639-648.

7. Fitt, B. D. L., Gregory, P. H., Todd, A., McCartney, H. A., and MacDonald, O. C. 1987. Spore dispersal and plant disease gradients, a comparison between two empirical models. J. Phytopathol.118:227-242.

8. Fitt, B. D. L., Lapwood, D. H., and Dance, S. J. 1983. Dispersal of Erwinia carotovora subsp. atroseptica in splash droplets. Potato Res. 26:123-131.

9. Fitt, B. D. L., McCartney, H. A., and Walklate, P. J. 1989. The role of rain in dispersal of pathogen inoculum. Annu. Rev. Phytopathol. 27:241-270.

10. Goto, M., and Yaguchi, Y. 1979. Relationship between defoliation and disease severity in citrus canker (Xanthomonas citri). Ann. Phytopathol. Soc. Jpn. 45:689-694.

11. Gottwald, T., Graham, J., Schubert ,T., and Sun, X. 1997. Analysis of the dynamics of spread of citrus canker in urban Miami, Florida. Phytopathology 87:S34-S35.

12. Gottwald, T. R., Civerolo, E. L., Garnsey, S. M., Brlansky, R. H., Graham, J. H., and Gabriel, D. W. 1988. Dynamics and spatial distribution of Xanthomonas campestris pv. citri group E strains in simulated nursery and new grove situations. Plant Dis. 72:781-787.

13. Gottwald, T. R., Graham, J. H., and Engel, D. S. 1992. Analysis of foci of Asiatic citrus canker in a Florida citrus orchard. Plant Dis. 76:389-396.

14. Gottwald, T. R., Graham J. H., and Schubert, T. S. 1997. An epidemiological analysis of the spread of citrus canker in urban Miami, Florida, and synergistic interaction with the Asian citrus leaf miner. Fruits, Paris 52:383-390.

15. Gottwald, T. R., Hughes, G., Graham, J. H., Sun, X., and Riley, T. 2001. The citrus canker epidemic in Florida: The scientific basis of regulatory eradication policy for an invasive species. Phytopathology 91:30-34.

16. Gottwald, T. R., Reynolds, K. M., Campbell, C. L., and Timmer, L. W. 1992. Spatial and spatiotemporal autocorrelation analysis of citrus canker epidemics in citrus nurseries and groves in Argentina. Phytopathology 82:843851.

17. Gottwald, T. R., Sun, X., Riley, T., Graham, J. H., Ferrandino, F., and Taylor, E. L. 2002. Geo-referenced spatiotemporal analysis of the urban citrus canker epidemic in Florida. Phytopathology 92:361-377.
18. Gottwald, T. R., and Timmer, L. W. 1995. The efficacy of windbreaks in reducing the spread of citrus canker caused by Xanthomonas campestris pv. citri. Trop. Agric. 72:194201.

19. Gottwald, T. R., Timmer, L. W., and McGuire, R. G. 1989. Analysis of disease progress of citrus canker in nurseries in Argentina. Phytopathology 79:1276-1283.

20. Gregory, P. H. 1968. Interpreting plant disease dispersal gradients. Annu. Rev. Phytopathol. 6:189-212.

21. Koizumi, M. 1977. Behaviour of Xanthomonas citri (Hasse) Dowson and histological changes of diseased tissue in the process of lesion extension. Ann. Phytopathol. Soc. Jpn. 43:129136.

22. Koizumi, M. 1985. Citrus canker: The world situation. Pages 2-7 in: Citrus Canker: An International Perspective. L. W. Timmer, ed. University of Florida, Lake Alfred.

23. Madden, L. V. 1992. Rainfall and the dispersa of fungal spores. Adv. Plant Pathol. 8:39-79.

24. Mundt, C. C., Ahmed, H. U., Finckh, M. R. Nieva, L. P., and Alfonso, R. F. 1999. Primary disease gradients of bacterial blight of rice. Phytopathology 89:64-67.

25. Mundt, C. C., and Leonard, K. J. 1985. A modification of Gregory's model for describing plant disease gradients. Phytopathology 75:930-935.

26. Peltier, G. L. 1920. Influence of temperature and humidity on the growth of Pseudomonas citri and its host plants and on infection and development of the disease. J. Agric. Res. 20:447-506.

27. Pruvost, O., Boher, B., Brocherieux, C Nicole, M., and Chiroleu, F. 2002. Survival of Xanthomonas axonopodis pv. citri in leaf lesions under tropical environmental conditions and simulated splash dispersal of inoculum. Phytopathology 92:336-346.

28. Schubert, T. S., Rizvi, S. A., Sun, $X$ Gottwald, T. R., Graham, J. H., and Dixon, W. N. 2001. Meeting the challenge of eradicating citrus canker in Florida-again. Plant Dis. 85:340-356.

29. Serizawa, S. 1981. Recent studies on the behaviour of the causal bacterium of the citrus canker. Proc. Int. Soc. Citric. 1:395-397.

30. Serizawa, S., Inoue, K., and Goto, M. 1969. Studies on citrus canker I. Dispersal of the citrus canker organism. Bull. Schizuoka Pref. Citrus Exp. Stn. 8:81-85.

31. Stall, R. E., Miller, J. W., Marco, G. M., and deEchenique, B. I. C. 1980. Population dynamics of Xanthomonas citri causing cancrosis of citrus in Argentina. Proc. Fla. State Hortic. Soc. 93:10-14.

32. Timmer, L. W., Gottwald, T. R., and Zitko, S. E. 1991. Bacterial exudation from lesions of Asiatic citrus canker and citrus bacterial spot. Plant Dis. 75:192-195.

33. Upper, C. D., and Hirano, S. S. 1991. Aerial dispersal of bacteria. Pages 75-93 in: Assessing Ecological Risks of Biotechnology. L. R. Ginzburg, ed. Butterworth, Stoneham, MA

34. Venette, J. R., and Kennedy, B. W. 1975. Naturally produced aerosol of Pseudomonas glycinea. Phytopathology 65:737-738. 